\title{
ANALISIS PENGARUH INFLASI DAN BI RATE TERHADAP RETURN ON ASSETS (ROA) BANK SYARIAH DI INDONESIA
}

\author{
Syahirul Alim \\ E-mail : syahirul_alim@pbs.uin-malang.ac.id
}

\begin{abstract}
Abstrak: Penelitian ini dilakukan dengan menggunakan metode kuantitatif dengan data sekunder yang diperoleh dari website Bank Indonesia. Data yang digunakan merupakan data runtut waktu dari bulan Oktober 2008 sampai dengan Oktober 2013. Analisis data menggunakan uji asumsi klasik yang terdiri dari : (a) Uji Normalitas; (b) Uji Multikolinearitas; (c) Uji Heteroskedastisitas; (d) Uji Autokorelasi. Selanjutnya digunakan uji statistik yang terdiri dari; (a) Uji T; (b) Uji F; dan (c) Uji Koefisien Determinasi. Berdasarkan hasil penelitian ini diperoleh kesimpulan sebagai berikut : (a) Inflasi berpengaruh positif dan tidak signifikan terhadap Return On Assets (ROA) ; (b) BI Rate berpengaruh negatif dan tidak signifikan terhadap Return On Assets (ROA) ; (c) Inflasi dan BI Rate secara bersamasama tidak memiliki pengaruh signifikan terhadap Return On Assets (ROA) ; (d) Variabel inflasi dan BI Rate hanya mampu menjelaskan $1,8 \%$ dari terjadinya perubahan nilai Return On Assets (ROA) Bank Syariah di Indonesia. Sehingga dapat disimpulkan bahwa variabel inflasi dan BI Rate hanya memiliki pengaruh yang rendah dan tidak signifikan terhadap Return On Assets. Hal ini dikarenakan sistem operasional Bank Syariah yang tidak menggunakan bunga, sehingga pengaruh inflasi dan BI Rate hanya sedikit memengaruhi resiko operasional dan resiko kredit. Diharapkan bagi perbankan syariah untuk terus memantau nisbah bagi hasil dan margin yang ditawarkan kepada nasabah supaya nilai Return On Assets tidak mengalami penurunan apabila terjadi krisis moneter yang disebabkan oleh inflasi dan BI Rate.
\end{abstract}

Kata kunci : Inflasi, BI Rate, Return On Assets (ROA) Bank Syariah

\section{PENDAHULUAN}

Krisis ekonomi global yang terjadi pada tahun 2008 membawa dampak adanya krisis di Indonesia. Meskipun tidak separah yang terjadi pada krisis moneter tahun 1998, hal ini mengakibatkan terjadinya gejolak ekonomi di sebagian besar Negara di dunia, termasuk di Indonesia. Dampak pada perekonomian Indonesia mulai terasa pada akhir triwulan 2008 yang ditandai dengan turunnya Indeks Harga Saham Gabungan (IHSG) pada bulan Desember

Syahirul Alim, adalah Dosen Prodi Akuntansi UIN MALIKI Malang 
2008 yang ditutup pada level 1.355,4 yang turun drastis dari level 2.627,3 pada awal tahun 2008. Penurunan IHSG ini juga bersamaan dengan jatuhnya nilai kapitalisasi pasar dan penurunan tajam volume perdagangan saham (Outlook Ekonomi Indonesia 2009-2014, edisi Januari 2009).

Namun kondisi perekonomian ini ternyata tidak berpengaruh terhadap kondisi keuangan Bank Syariah. Hal ini dikarenakan sistem operasional Bank Syariah yang tidak menggunakan sistem bunga, sehingga tidak terlalu berisiko apabila kondisi keuangan dunia yang umumnya berbasis bunga mengalami penurunan.

Selain itu, dampak krisis moneter juga mengakibatkan adanya inflasi, yang menyebabkan harga barang-barang naik dan kemampuan membeli masyarakat menjadi terbatas. Inflasi diartikan sebagai meningkatnya harga-harga secara terus-menerus. Inflasi timbul karena adanya tekanan dari sisi supply (cost push inflation), dari sisi permintaan (demand pull inflation), dan dari ekspektasi inflasi (dalam website www.bi.go.id, tahun 2014). Sehingga kestabilan inflasi sangat penting karena inflasi yang tidak stabil dapat memicu melemahnya nilai tukar rupiah dan menjadi salah satu faktor penyebab terjadinya krisis moneter.

Faktor utama selain inflasi yang menyebabkan terjadinya krisis moneter adalah tingkat suku bunga atau BI Rate perbankan. Website www.bi.go.id (2014) menjelaskan, BI Rate adalah suku bunga kebijakan yang mencerminkan sikap kebijakan moneter yang ditetapkan oleh Bank Indonesia dan diumumkan kepada publik. BI Rate diumumkan oleh Dewan Gubernur Bank Indonesia setiap rapat dewan gubernur bulanan dan diimplementasikan pada operasi moneter yang dilakukan Bank Indonesia melalui pengelolaan likuiditas di pasar uang untuk mencapai sasaran operasional kebijakan moneter.

Pada saat terjadinya krisis moneter, bank syariah tidak mengalami pergerakan negatif seperti halnya bank konvensional. Hal ini dikarenakan Bank syariah merupakan lembaga keuangan pencari laba, namun dilarang berusaha dengan riba dan terlibat dengan perdagangan yang tidak sesuai dengan prinsipprinsip syariah (Kamal Khir,dkk., 2008 dalam Iska, 2012:27). Sehingga dalam setiap transaksi keuangannya Bank Syariah tidak menggunakan suku bunga sebagai acuan, dan menyebabkan kinerja keuangan Bank Syariah tidak terlalu terpengaruh oleh inflasi.

Salah satu indikator untuk menilai kinerja keuangan bank adalah melihat tingkat profitabilitas dan efisiensinya. Rasio Profitabilitas adalah sekelompok rasio yang menunjukkan kombinasi dari pengaruh likuiditas, manajemen aset, dan utang pada hasil operasi (Houston, 2004: 146). Dalam rasio profitabilitas, rasio yang paling menonjol adalah Return On Assets (ROA) yang merupakan rasio laba bersih terhadap total aset.

Dalam Return On Assets (ROA), akan terlihat kemampuan bank dalam menghasilkan laba bersih dengan membandingkan total aset yang dimiliki. Sehingga apabila semakin besar ROA suatu bank, maka tingkat keuntungan yang didapat oleh bank juga semakin besar. Hal ini berbeda dengan Return On Equity (ROE) yang berfokus pada tingkat pengembalian ekuitas kepada pemilik saham perusahaan yang bersangkutan, sehingga ROE berperan untuk menarik minat para investor dalam berinvestasi. Semakin besar nilai ROE, maka semakin bagus tingkat investasi yang ditawarkan perusahaan tersebut. 
Sehingga berdasarkan perbedaan antara ROA dan ROE tersebut, penulis tertarik untuk mengkaji ROA, karena ROA berhubungan langsung dengan tingkat keuntungan bank dan menjadi salah satu faktor penting bank tersebut memiliki stabilitas keuangan yang baik.

Berikut adalah tabel Return On Assets (ROA) Bank Syariah dan Unit Usaha Syariah (UUS) dalam kurun waktu 2008-2011 :

Tabel 1.

Return On Assets (ROA) Bank Syariah

periode 2008-2011

\begin{tabular}{|l|l|l|l|l|}
\hline & \multicolumn{1}{|c|}{2008} & 2009 & 2010 & 2011 \\
\hline $\begin{array}{l}\text { Return On } \\
\text { Assets (ROA) }\end{array}$ & $1.42 \%$ & $1.48 \%$ & $1.67 \%$ & $1.79 \%$ \\
\hline
\end{tabular}

Sumber : Statistik Perbankan Syariah (2013), data diolah

Pada akhir triwulan 2013, kondisi ekonomi Indonesia menunjukkan adanya perbaikan, hal ini dilihat dari menurunnya defisit transaksi berjalan secara signifikan pada triwulan IV 2013. Neraca Pembayaran Indonesia (NPI) juga mencatat adanya surplus dan diikuti dengan meredanya nilai tukar rupiah (Laporan Perekonomian Indonesia BI, Tahun 2013). Sehingga alasan inilah yang menyebabkan peneliti mengkaji data dari bulan Oktober 2008 s/d Oktober 2013 dikarenakan perbedaan kondisi ekonomi di pada tahun 2008 yang mengalami penurunan, dan pada tahun 2013 mengalami peningkatan kondisi ekonomi.

Berdasarkan data Return On Assets (ROA) Bank Syariah di Indonesia seperti yang tercantum pada tabel diatas, terlihat bahwa ROA mengalami peningkatan, meskipun kondisi perekonomian global pada tahun 2008-2011 mengalami krisis finansial. Hal ini diperkuat dengan penelitian Supriyanti (2009) bahwa inflasi dan suku bunga tidak memiliki pengaruh signifikan terhadap Return On Assets (ROA). Sehingga hal inilah yang membuat penulis tertarik untuk mengkaji pengaruh inflasi dan BI rate terhadap Return On Assets (ROA) Bank Syariah di Indonesia.

Berdasarkan latar belakang diatas, rumusan penelitian dapat diuraikan sebagai berikut :

a. Bagaimana pengaruh inflasi secara parsial terhadap Return On Assets (ROA) Bank Syariah di Indonesia ?

b. Bagaimana pengaruh BI Rate secara parsial terhadap Return On Assets (ROA) Bank Syariah di Indonesia ?

c. Bagaimana pengaruh inflasi dan BI Rate secara simultan terhadap Return On Assets (ROA) Bank Syariah di Indonesia?

\section{TINJAUAN PUSTAKA}

\section{BANK SYARIAH}

\section{Pengertian dan Dasar Hukum Bank Syariah}

Bank Syariah adalah lembaga keuangan yang usaha pokoknya memberikan pembiayaan dan jasa-jasa lainnya dalam lalu lintas pembayaran serta peredaran uang yang pengoperasiannya disesuaikan dengan prinsip syariat Islam 
(Muhammad, 2005:1). Said Sa'ad Marthan (2001) dalam Iska (2012:50) mengungkapkan bahwa bank syariah ialah lembaga investasi yang beroperasi sesuai dengan asas-asas syariah. Sumber dana yang dikelola harus sesuai dengan syar'i dan tujuan alokasi investasi yang dilakukan yaitu membangun ekonomi dan sosial masyarakat serta melakukan pelayanan perbankan yang sesuai dengan nilainilai syariah. Menurut Antonio (1992) dalam Iska (2012:50) Bank syariah memiliki dua pengertian yaitu :

a. Bank yang beroperasi sesuai dengan asas-asas syariah Islam

b. Bank yang beroperasi mengikuti aturan dan tata cara yang ada pada AlQur'an dan Hadits.

Dasar hukum perbankan syariah juga mendapat legalitas setelah adanya deregulasi sektor perbankan pada tahun 1983 .Hal ini dikarenakan pada saat itu terdapat keleluasaan penentuan tingkat suku bunga, termasuk nol persen atau peniadaan bunga sekaligus (Muhammad, 2005:3). Pembentukan Undang-Undang yang mengatur terkait perbankan syariah juga dibentuk pada tahun 1992 dalam bentuk UU No.7 Tahun 1992 dan disempurnakan pada UU No 10 Tahun 1998. Untuk menjalankan Undang-Undang tersebut dikeluarkan pula Surat Keputusan Direksi Bank Indonesia tentang Bank Umum dan Bank Perkreditan Rakyat Tahun 1999 dilengkapi Bank Umum Berdasarkan Prinsip Syariah dan Bank Perkreditan Rakyat Berdasarkan Prinsip Syariah.

Aturan tersebut termuat dalam Surat Keputusan Direksi Bank Indonesia No. 32/34/KEP/DIR tgl. 12 Mei 1999 yang meliputi :

a. Pasal 1 huruf a menyatakan, "Bank adalah Bank Umum sebagaimana dimaksud dalam Pasal 1 angka 3 Undang-Undang Nomor 7 tahun 1992 tentang Perbankan sebagaimana telah diubah dengan Undang-Undang Nomor 10 Tahun 1998, yang melakukan kegiatan usaha berdasarkan prinsip syariah."

b. Pasal 1 huruf g menyatakan," Kegiatan Usaha berdasarkan Prinsip Syariah adalah kegiatan usaha perbankan yang dilakukan berdasarkan prinsip Syariah sebagaimana dimaksud dalam Pasal 1 angka 13 Undang-Undang No.7 Tahun 1992 tentang Perbankan sebagaimana telah diubah dengan Undang-Undang No.10 Tahun 1998."

\section{Perbedaan Bank Syariah dengan Bank Konvensional}

Perbedaan sistem operasi Bank Syariah dan Bank Konvensional terlihat dari adanya sistem operasi yang berbasis bagi hasil dan riba. Perbedaan antara keduanya dapat dilihat pada tabel berikut (Antonio, 2001 dalam Iska, 2012:26)

Tabel 2.

Perbedaan Bank Syariah dan Bank Konvensional

\begin{tabular}{|c|l|l|}
\hline No. & \multicolumn{1}{|c|}{ Bank Syariah } & \multicolumn{1}{c|}{ Bank Konvensional } \\
\hline 1. & Melakukan investasi yang halal saja & Investasi yang halal dan haram \\
\hline 2. & $\begin{array}{l}\text { Berdasarkan prinsip bagi hasil } \\
\text { untung/rugi, jual beli, dan sewa }\end{array}$ & Memakai perangkat bunga \\
\hline 3. & Profit dan falah oriented & Profit oriented \\
\hline
\end{tabular}


Perbedaan sistem bunga dan sistem bagi hasil dijelaskan pada tabel berikut (Muhammad, 2005:3) :

Tabel 3

Perbedaan Sistem Bunga dan Sistem Bagi Hasil

\begin{tabular}{|c|c|c|c|}
\hline No. & Hal & Sistem Bunga & Sistem Bagi Hasil \\
\hline 1. & $\begin{array}{l}\text { Penentuan } \\
\text { besarnya hasil }\end{array}$ & $\begin{array}{l}\text { Sebelum melakukan } \\
\text { usaha }\end{array}$ & $\begin{array}{ll}\text { Sesudah melakukan } \\
\text { usaha }\end{array}$ \\
\hline 2. & $\begin{array}{l}\text { Yang ditentukan } \\
\text { sebelumnya }\end{array}$ & $\begin{array}{l}\text { Bunga, besarnya nilai } \\
\text { rupiah }\end{array}$ & $\begin{array}{l}\text { Menyepakati proporsi } \\
\text { pembagian untung untuk } \\
\text { masing-masing pihak }\end{array}$ \\
\hline 3. & $\begin{array}{ll}\text { Jika } & \text { terjadi } \\
\text { kerugian } & \end{array}$ & $\begin{array}{l}\text { Ditanggung nasabah } \\
\text { saja }\end{array}$ & $\begin{array}{l}\text { Ditanggung kedua belah } \\
\text { pihak, nasabah dan } \\
\text { lembaga }\end{array}$ \\
\hline 4. & Dihitung dari & $\begin{array}{l}\text { Dari dana yang yang } \\
\text { dipinjamkan } \\
\text { bersifat tetap }\end{array}$ & $\begin{array}{l}\text { Dari keuntungan usaha } \\
\text { yang akan diperoleh }\end{array}$ \\
\hline 5. & $\begin{array}{l}\text { Titik Perhatian } \\
\text { Proyek/ Usaha }\end{array}$ & $\begin{array}{l}\text { Besarnya bunga yang } \\
\text { harus dibayar nasabah / } \\
\text { pasti diterima bank }\end{array}$ & $\begin{array}{lr}\text { Keberhasilan } & \text { proyek } \\
\text { menjadi perhatian } \\
\text { bersama antara nasabah } \\
\text { dan lembaga }\end{array}$ \\
\hline 6. & Besar Keuntungan & $\begin{array}{lr}\text { Pasti, } & \text { tergantung } \\
\text { prosentase } & \text { jumlah } \\
\text { pinjaman } & \end{array}$ & $\begin{array}{lr}\text { Tergantung proporsi } \\
\text { yang disepakati dan } \\
\text { dihitung } & \text { dari } \\
\text { keuntungan usaha yang } \\
\text { belum diketahui }\end{array}$ \\
\hline 7. & Status Hukum & $\begin{array}{lr}\text { Berlawanan } & \text { dengan } \\
\text { Q.S Lukman : } 34 \text { yaitu } \\
\text { menghindari } \\
\text { penggunaan sistem } \\
\text { yang menetapkan } \\
\text { dimuka secara pasti } \\
\text { keberhasilan ratu } \\
\text { usaha }\end{array}$ & $\begin{array}{l}\text { Melaksanakan Q.S } \\
\text { Lukman : } 34 \text { yaitu } \\
\text { menghindari } \\
\text { penggunaan sistem yang } \\
\text { menetapkan dimuka } \\
\text { secara pasti keberhasilan } \\
\text { suatu usaha }\end{array}$ \\
\hline
\end{tabular}

\section{Return On Assets (ROA)}

Return On Assets (ROA) adalah salah satu rasio yang digolongkan dalam Rasio Profitabilitas. Rasio Profitabilitas adalah sekelompok rasio yang menunjukkan kombinasi dari pengaruh likuiditas, manajemen aset, dan utang pada hasil operasi (Houston, 2004: 146). Menurut Lukman (2005) dalam Supriyanti (2009:6) Return On Assets (ROA) digunakan untuk mengukur manajemen bank dalam memperoleh keuntungan (laba) secara keseluruhan. Menurut Husnan (1992) dalam Sahara (2013:150), semakin besar Return On Assets (ROA) menunjukkan kinerja keuangan yang semakin baik karena tingkat kembalian (return) yang lebih besar. 
Berdasarkan ketentuan yang ditetapkan oleh Bank Indonesia, rumus untuk menghitung Return On Assets adalah sebagai berikut :

Laba Setelah Pajak

Total Aset

\section{INFLASI}

\section{Pengertian Inflasi}

Inflasi diartikan sebagai meningkatnya harga-harga secara terus-menerus. Boediono (1987) dalam Julianti (2013:23) menyatakan bahwa inflasi adalah kecenderungan dari harga-harga untuk menaikkan secara umum dan terusmenerus dalam jangka waktu yang lama. Kenaikan harga dari satu atau dua barang saja tidak disebut inflasi, kecuali bila kenaikan tersebut meluas kepada (atau mengakibatkan kenaikan) sebagian besar dari harga barang-barang lain.

Inflasi diukur dengan tingkat inflasi, yaitu tingkat perubahan dari tingkat harga secara umum. Persamaannya adalah sebagai berikut (Karim, 2007 : 136) :

Tingkat harga ${ }_{\mathrm{t}}-$ Tingkat harga $_{\mathrm{t}-1} \quad \mathrm{x} 100=$ Tingkat Inflasi

Tingkat harga $\mathrm{t}-1$

Artinya, semakin tinggi tingkat inflasi maka semakin besar selisih harga barang setelah adanya inflasi yang mengakibatkan harga barang menjadi lebih mahal.

\section{Penyebab Inflasi}

Inflasi timbul karena adanya 3 faktor sebagai berikut :

a. Tekanan dari sisi supply (cost push inflation)

Inflasi ini timbul karena adanya depresiasi nilai tukar, dampak inflasi luar negeri terutama negara-negara partner dagang, peningkatan harga-harga komoditi yang diatur pemerintah, dan terjadinya negative supply shocks akibat bencana alam atau terganggunya distribusi.

b. Dorongan permintaan (demand pull inflation)

Inflasi ini timbul apabila permintaan agregat meningkat lebih cepat dibandingkan dengan potensi produktif perekonomian.

c. Ekspektasi inflasi

Inflasi ini dipengaruhi oleh perilaku masyarakat dan pelaku ekonomi apakah lebih cenderung bersifat adaptif atau forward looking. Hal ini terlihat dari perilaku pembentukan harga di tingkat produsen dan pedagang terutama pada saat menjelang hari besar keagamaan dan penentuan upah minimum regional (dalam website www.bi.go.id, tahun 2014).

Sedangkan menurut Sukirno (2004) dalam Huda, Nurul, dkk. (2008:177), inflasi dibedakan menjadi 3 bentuk, yaitu : 
a. Inflasi Tarikan Permintaan, inflasi ini biasanya terjadi pada masa perekonomian berkembang pesat. Kesempatan kerja yang tinggi menciptakan tingkat pendapatan yang tinggi dan selanjutnya menimbulkan pengeluaran yang melebihi kemampuan ekonomi mengeluarkan barang dan jasa. Pengeluaran yang berlebihan ini yang akan menimbulkan inflasi.

b. Inflasi desakan biaya, inflasi ini juga terjadi pada saat perekonomian berkembang dengan pesat ketika tingkat pengangguran sangat rendah .

c. Inflasi diimpor, inflasi ini terjadi apabila barang-barang impor yang mengalami kenaikan mempunyai peranan yang penting dalam kegiatan pengeluaran di perusahaan-perusahaan, contohnya kenaikan harga minyak.

Dalam teori inflasi islam, inflasi berakibat sangat buruk bagi perekonomian karena :

a. Menimbulkan gangguan terhadap fungsi uang, terutama terhadap fungsi tabungan (nilai simpan), fungsi dari pembayaran di muka, dan fungsi dari unit penghitungan. Orang harus melepaskan diri dari uang dan aset keuangan akibat dari beban inflasi tersebut. Inflasi juga mengakibatkan terjadinya inflasi kembali.

b. Melemahkan semangat menabung dan sikap terhadap menabung dari masyarakat.

c. Meningkatkan kecenderungan untuk berbelanja terutama untuk nonprimer dan barang-barang mewah.

d. Mengarahkan investasi pada hal-hal yang non produktif yaitu penumpukan kekayaan seperti : tanah, bangunan, logam mulia, mata uang asing dengan mengorbankan investasi ke arah produktif seperti : pertanian, industrial, perdagangan, transportasi, dan lainnya (Karim, 2006:139).

Ekonom Islam Taqiudin Ahmad ibn al-Maqrizi menggolongkan inflasi ke dalam dua bentuk, yaitu :

a. Natural Inflation

Inflasi jenis ini diakibatkan oleh sebab-sebab alamiah dimana orang tidak mempunyai kendali atasnya, dan inflasi ini diakibatkan oleh turunnya Penawaran Agregartif (AS) atau naiknya Permintaan Agregatif (AD). Jika memakai perangkat analisis konvensional dengan persamaan identitas sebagai berikut :

$$
\mathrm{MV}=\mathrm{PT}=\mathrm{Y}
$$

$$
\begin{array}{ll}
\text { Dimana : } & \mathrm{M}=\text { jumlah uang beredar } \\
\mathrm{V} & =\text { kecepatan peredaran uang } \\
\mathrm{P} & =\text { tingkat harga } \\
\mathrm{T} & =\text { jumlah barang dan jasa } \\
\mathrm{Y} & =\text { tingkat pendapatan nasional (GDP) }
\end{array}
$$

Sehingga Natural Inflation bisa dijelaskan sebagai berikut : 
1) Gangguan terhadap jumlah barang dan jasa yang diproduksi dalam suatu perekonomian. Misalnya jumlah barang dan jasa turun tetapi jumlah uang beredar dan kecepatan peredaran uang tetap, maka konsekuensinya harga barang meningkat.

2) Naiknya daya beli masyarakat secara riil. Misalnya nilai ekspor lebih besar daripada nilai impor, sehingga secara netto terjadi impor uang yang mengakibatkan jumlah uang beredar turun. Apabila kondisi ini berlaku sedangkan kecepatan peredaran uang dan jumlah barang dan jasa tetap, maka harga akan meningkat.

\section{b. Human Error Inflation}

Human Error Inflation dikatakan sebagai inflasi yang diakibatkan oleh kesalahan manusia itu sendiri. Penyebab human error inflation bisa dikelompokkan sebagai berikut :

1) Korupsi dan administrasi yang buruk

2) Pajak yang berlebihan

3) Pencetakan uang dengan maksud menarik keuntungan yang berlebihan (Karim, 2006 : 140).

Sehingga Ekonom Islam juga memberikan solusi untuk menjaga kestabilan moneter sebagai berikut :

a. Melarang adanya transaksi yang bersifat gharar, seperti judi dan riba'.

b. Memaksimalkan sumber daya yang ada untuk dialokasikan pada kegiatan ekonomi produktif.

c. Menetapkan fungsi bank sentral secara optimal, dalam hal ini di Indonesia telah diberlakukan instrumen-instrumen pengendali moneter khusus perbankan syariah seperti : Giro Wajib Minimum, Sertifikat Investasi Mudharabah Antarbank Syariah (SIMA), dan Sertifikat Wadi'ah Bank Indonesia (Karim, 2006 : 233-234).

\section{Dampak Inflasi terhadap Return On Assets (ROA) Bank Syariah di Indonesia}

Inflasi termasuk salah satu indikator ekonomi makro yang berpengaruh terhadap kinerja keuangan perusahaan. Berdasarkan jurnal ilmiah dari Sahara (2013:153), Inflasi berpengaruh positif terhadap Return On Assets (ROA) Bank Syariah, yang berarti semakin tinggi tingkat inflasi maka semakin besar (ROA) Bank Syariah. Kenaikan inflasi akan diikuti dengan kenaikan aset dan Dana Pihak Ketiga (DPK) Bank Syariah, yang akan meningkatkan profitabilitas Bank Syariah dari sisi Return On Assets (ROA).

\section{BI RATE}

\section{Pengertian BI Rate}

BI Rate adalah suku bunga kebijakan yang mencerminkan sikap kebijakan moneter yang ditetapkan oleh Bank Indonesia dan diumumkan kepada publik. BI Rate merupakan indikasi suku bunga jangka pendek yang diinginkan Bank Indonesia dalam upaya mencapai target inflasi. BI Rate digunakan sebagai acuan dalam operasi moneter untuk mengarahkan agar suku bunga Sertifikat Bank Indonesia (SBI) 1 bulan hasil lelang operasi pasar terbuka berada di sekitar BI Rate (dalam website www.bi.go.id). 
Menurut Pohan (2008 : 53) Perkembangan tingkat bunga yang tidak wajar secara langsung dapat mengganggu perkembangan perbankan. Suku bunga yang tinggi di satu sisi akan meningkatkan hasrat masyarakat untuk menabung sehingga jumlah dana perbankan akan meningkat. Namun di sisi lain suku bunga yang tinggi akan meningkatkan biaya yang dikeluarkan oleh dunia usaha sehingga mengakibatkan penurunan kegiatan produksi di dalam negeri. Menurunnya produksi akan menurunkan kebutuhan dana dari sektor usaha dan berakibat pada permintaan kredit bunga yang menurun. Hal ini akan menimbulkan permasalahan kemana dana tersebut akan disalurkan.

Selanjutnya apabila tingkat bunga relatif rendah apabila dibandingkan dengan tingkat bunga luar negeri, akan mengurangi minat masyarakat untuk menabung dan mendorong aliran dana dari dalam negeri ke luar negeri sehingga bank akan kesulitan dalam memeroleh dana. Tetapi pada sektor usaha, akan meningkatkan potensi kegiatan investasi dan produksi karena tingkat suku bunga yang rendah akan meningkatkan kredit perbankan (Pohan, $2008: 54$ ).

Sehingga kebijakan moneter sangat dipengaruhi oleh ketepatan tingkat suku bunga yang ideal, harus tercipta keseimbangan antara manfaat suku bunga bagi sektor perbankan dan dunia usaha, supaya kestabilan ekonomi Negara tetap terjaga.

\section{Sertifikat Wadi'ah Bank Indonesia (SWBI)}

Dalam kegiatan perekonomian terdapat siklus ekonomi, dimana ada saatnya ekonomi mengalami peningkatan dan penurunan. Penurunan ekonomi dikarenakan oleh terlalu banyaknya uang beredar yang dapat menyebabkan inflasi. Bank Indonesia bertugas menjaga kestabilan rupiah dan ekonomi dengan cara mengatur jumlah uang beredar melalui operasi pasar terbuka. Salah satu instrumen dalam operasi pasar terbuka tersebut adalah Sertifikat Bank Indonesia (SBI) yang digunakan untuk menyerap kelebihan likuiditas yang ada dimasyarakat. SBI ini diperjualbelikan antara Bank Indonesia selaku penerbit dengan Bank Konvensional dengan menggunakan sistem bunga.

Namun dengan adanya Bank Syariah di Indonesia, operasi pasar terbuka melalui Sertifikat Bank Indonesia (SBI) akan sulit untuk diaplikasikan karena menggunakan sistem bunga. Untuk itulah demi menjaga kestabilan moneter, Bank Indonesia menerbitkan Sertifikat Wadi'ah Bank Indonesia (SWBI). SWBI merupakan instrumen pengendalian moneter dengan sistem yang serupa dengan SBI, yaitu untuk menyerap kelebihan likuiditas jangka pendek dari bank, namun menggunakan sistem operasional secara syar'i yaitu akad wadi'ah. Akad wadi'ah merupakan akad titipan dimana Bank Indonesia tidak memberikan imbalan sesuai yang dijanjikan, namun boleh memberikan bonus di akhir akad dengan syarat tidak diperjanjikan di awal akad. Lebih jelasnya mengenai SWBI dapat dilihat pada lampiran.

\section{Dampak BI Rate terhadap Return On Assets (ROA) Bank Syariah di Indonesia}

Menurut Supriyanti (2009:17) BI rate tidak terlalu dominan dalam memengaruhi Return On Assets (ROA). Namun inflasi yang tinggi mengakibatkan naiknya $B I$ rate dan mengakibatkan bank mengeluarkan biaya 
operasional yang lebih besar dan memengaruhi profitabilitas bank. Hal ini dikarenakan calon nasabah akan lebih tertarik pada bank yang menawarkan suku bunga lebih tinggi.

Sedangkan menurut Sahara (2013) BI Rate berpengaruh negatif terhadap Return On Assets (ROA) Bank Syariah di Indonesia. Hal ini berarti meningkatnya suku bunga BI akan diikuti dengan naiknya suku bunga tabungan konvensional yang menyebabkan nasabah memindahkan dananya dari bank syariah ke bank konvensional. Selain itu, naiknya suku bunga bank konvensional akan memengaruhi kegiatan operasional bank syariah dalam hal pembiayaan dan penyaluran dana, sehingga pendapatan dan profit bank syariah akan menurun (Karim, 2006:255).

\section{Kerangka Konseptual}

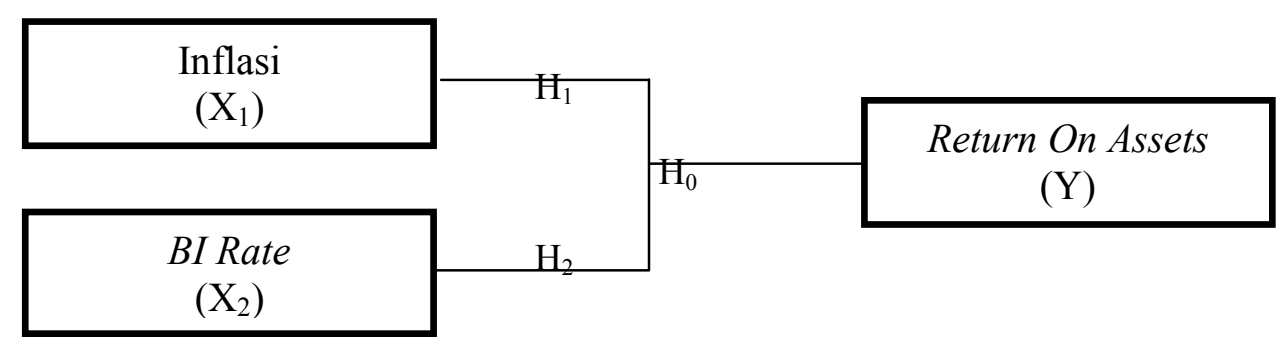

Gambar 1. Kerangka Konseptual

Keterangan :

$\mathrm{X}_{1}$ : Inflasi

$\mathrm{X}_{2}$ : BI Rate

$\mathrm{Y}:$ Return On Assets

Kerangka konseptual penelitian diatas dijelaskan sebagai berikut :

a. Menguji variabel independen, yaitu inflasi $\left(\mathrm{X}_{1}\right)$ dan $B I$ rate $\left(\mathrm{X}_{2}\right)$ berpengaruh terhadap variabel dependen yaitu Return On Assets (Y) secara parsial (individu) dengan menggunakan Uji T.

b. Menguji variabel independen, yaitu inflasi $\left(\mathrm{X}_{1}\right)$ dan $B I$ rate $\left(\mathrm{X}_{2}\right)$ berpengaruh terhadap variabel dependen yaitu Return On Assets (Y) secara simultan (bersama-sama) dengan menggunakan Uji F.

\section{Hipotesis}

Berdasarkan hubungan antara tujuan penelitian serta kerangka pemikiran teoritis terhadap rumusan masalah penelitian ini, maka hipotesis yang diajukan adalah sebagai berikut :

$\mathrm{H}_{1}$ : Diduga Inflasi berpengaruh positif dan signifikan terhadap

Return On Assets (ROA) Bank Syariah.

$\mathrm{H}_{2}$ : Diduga $B I$ Rate berpengaruh positif dan signifikan terhadap Return On

Assets (ROA) Bank Syariah.

$\mathrm{H}_{0}$ : Diduga tidak terjadi hubungan signifikan antara inflasi dan BI Rate

terhadap Return On Assets (ROA) Bank Syariah. 


\section{METODE}

Penelitian ini membahas mengenai pengaruh inflasi dan BI Rate terhadap Return On Assets (ROA) Bank Syariah di Indonesia. Jenis penelitian ini menggunakan penelitian kuantitatif dengan pendekatan kausalitas menggunakan analisis regresi.

Data yang digunakan pada penelitian ini menurut sumbernya merupakan data sekunder, dan menurut dimensi waktu menggunakan data runtut waktu (time series). Dalam penelitian ini data runtut waktu yang digunakan adalah data dalam skala bulanan dalam periode Oktober 2008 s/d Oktober 2013. Pemilihan data diawali pada bulan Oktober 2008 dikarenakan menjelang akhir triwulan 2008 perekonomian dunia mengalami krisis finansial sebagai dampak runtuhnya stabilitas ekonomi global. Krisis finansial ini diawali dari pembekuan beberapa sekuritas terkait kredit perumahan berisiko tinggi pada bulan Agustus 2007 oleh bank terbesar di Perancis, yaitu BNP Paribas yang berimbas pada kebangkrutan bank investasi terbesar di Amerika Serikat yaitu AS Lehman Brothers. Kondisi ini menyebabkan kesulitan keuangan berskala besar pada lembaga keuangan di Amerika, Jepang, Eropa, dan seluruh dunia.

Pengumpulan data dalam penelitian ini menggunakan metode dokumenter. Analisa data yang digunakan dalam penelitian ini menggunakan studi kausalitas dengan analisis regresi linear berganda. Analisis regresi umumnya digunakan apabila tujuan analisis adalah prediksi hubungan sebab akibat antara variabel independen dan variabel dependen (Kuncoro, 2007:75). Aplikasi yang digunakan untuk mendukung analisis data ini adalah dengan menggunakan aplikasi SPSS 16.

\section{PEMBAHASAN}

\section{INFLASI}

Berikut adalah data inflasi selama kurun waktu Oktober 2008 s/d Oktober 2013.

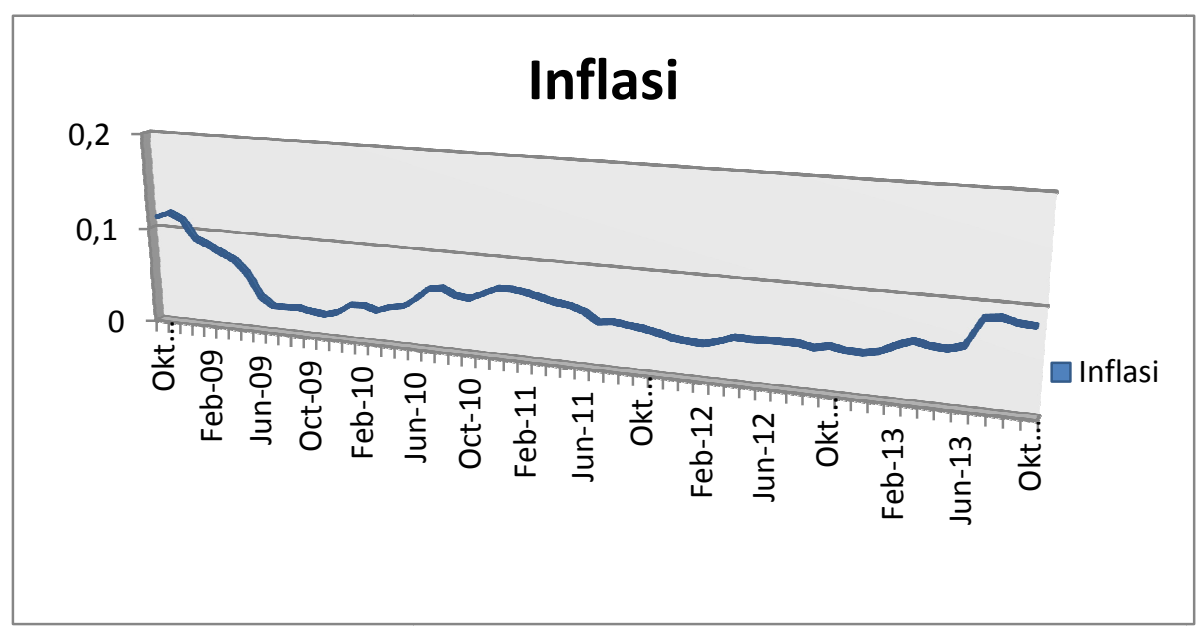

Gambar 2. Grafik Inflasi 
Dari gambar diatas terlihat bahwa nilai inflasi paling tinggi terjadi pada bulan November 2008, yaitu bernilai 0,1168 atau $11,68 \%$ dan nilai inflasi paling rendah terjadi pada bulan November 2009, yaitu bernilai 0,0241 atau 2,41 \%.

Nilai inflasi yang tinggi pada bulan November 2008 dikarenakan kondisi makro ekonomi Indonesia yang melambat pada triwulan-IV 2008. Hal ini bersumber dari perlambatan ekonomi dunia dan krisis keuangan global akibat permasalahan sektor perumahan di Amerika Serikat. Sementara itu, nilai inflasi paling rendah terjadi pada bulan November 2009, sekaligus merupakan nilai inflasi terendah selama satu dekade terakhir. Hal ini dikarenakan membaiknya perekonomian Indonesia semenjak memasuki triwulan-II 2009 sebagai dampak positif kebijakan moneter Bank Indonesia dan Pemerintah.

\section{BI RATE}

Berikut adalah data BI Rate selama kurun waktu Oktober 2008 s/d Oktober 2013.

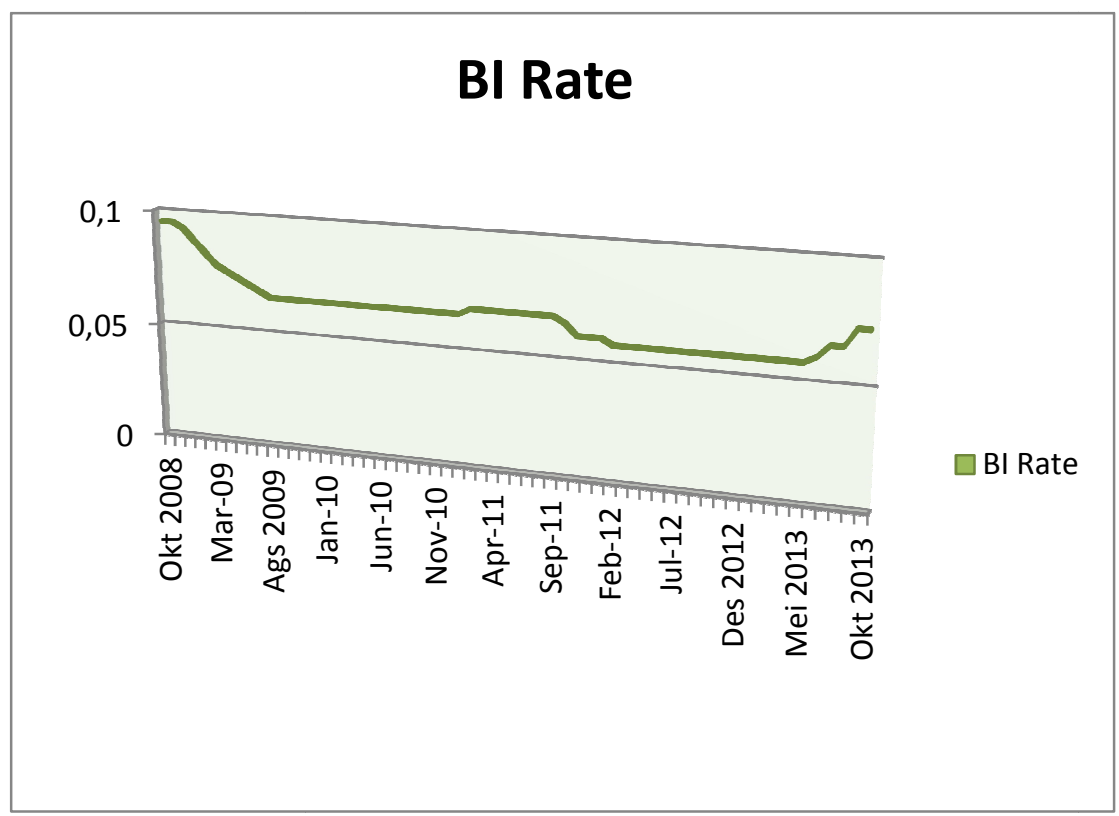

\section{Gambar 3. Grafik BI Rate}

Dibandingkan dengan nilai inflasi, nilai BI Rate terlihat cukup stabil, hal ini terlihat dari bentuk grafik yang tidak fluktuatif apabila dibandingkan dengan grafik Inflasi. Nilai BI Rate paling tinggi terjadi pada bulan Oktober s/d November 2008 dengan nilai 0.095 atau 9,5 \%. Hal ini juga dikarenakan perekonomian Indonesia yang menurun pasca krisis ekonomi global tahun 2008. Sedangkan nilai BI Rate terendah terjadi pada bulan Februari 2012 s/d Mei 2013 dengan nilai sebesar 0.0575 atau $5,75 \%$. Untuk data selengkapnya dapat dilihat pada lampiran. 


\section{Data Variabel Dependen (Return On Assets)}

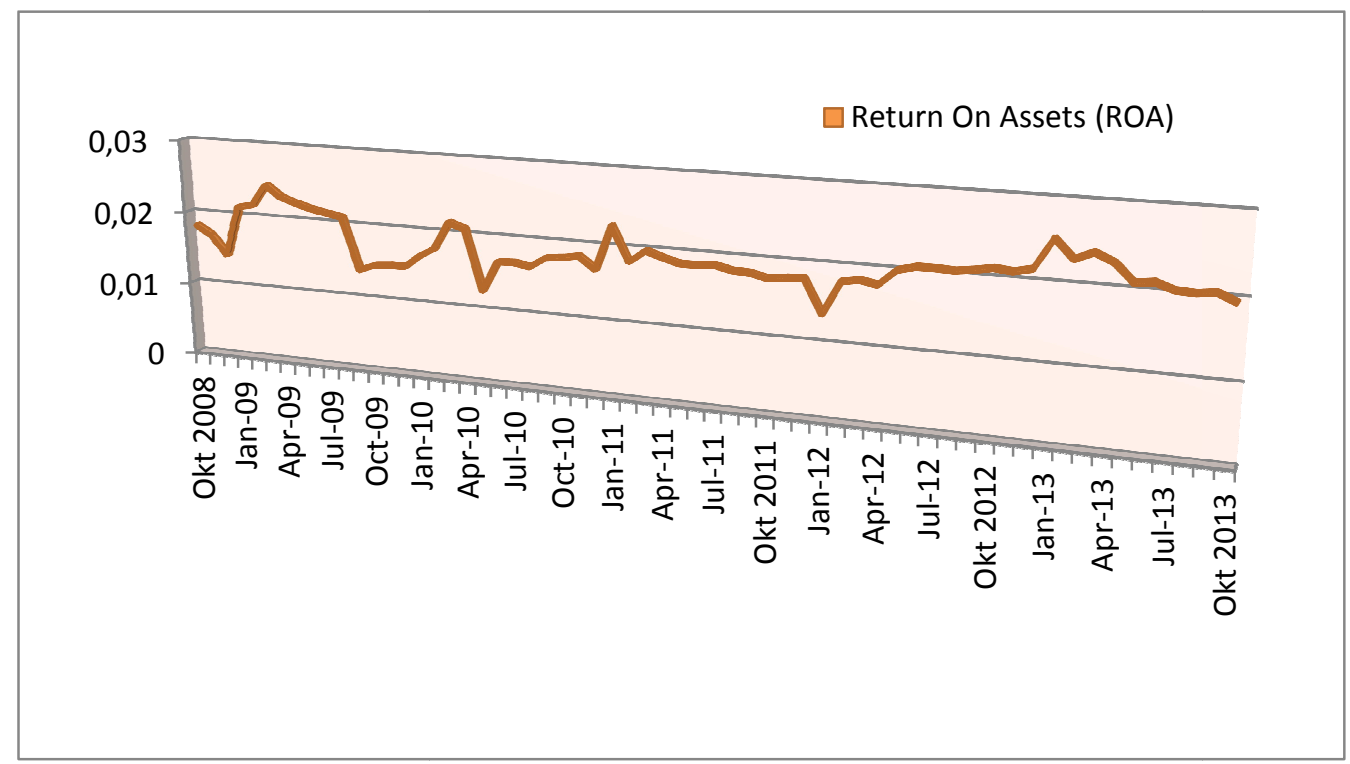

Gambar 4. Grafik Return On Assets (ROA)

Di Indonesia dalam kurun waktu Oktober 2008 s/d Oktober 2013. Dari gambar diatas, terlihat bahwa nilai Return On Assets tertinggi terjadi pada bulan Januari 2013 dengan nilai 0,0252 atau 2,52 \%. Dilansir dari website Bank Indonesia, hal ini dikarenakan Bank Indonesia menerapkan bauran kebijakan yang sangat ketat guna menjaga stabilitas perekonomian. Sedangkan nilai Return On Assets terendah terjadi pada bulan Mei 2010 dengan nilai 0,0125 atau 1,25\%. Untuk data Return On Assets bulanan lebih lengkap dapat dilihat pada lampiran.

\section{Uji Statistik}

Hasil uji statistic mengenai hubungan antara pengaruh inflasi dan BI Rate terhadap Return On Assets (ROA) Bank Syariah melalui uji statistik berikut ini :

\section{Uji T}

Uji T dilakukan untuk mengetahui pengaruh variabel independen, yaitu inflasi dan $B I$ Rate secara parsial (individu) terhadap variabel dependen, yaitu Return On Assets (ROA).

Tabel 4. Uji T

\begin{tabular}{|c|c|c|c|c|c|c|c|c|}
\hline \multicolumn{9}{|c|}{ Coefficients $^{\mathrm{a}}$} \\
\hline & & \multicolumn{2}{|c|}{$\begin{array}{l}\text { Unstandardized } \\
\text { Coefficients }\end{array}$} & \multirow{2}{*}{$\begin{array}{l}\text { Standardized } \\
\text { Coefficients } \\
\text { Beta }\end{array}$} & \multirow[b]{2}{*}{$\mathrm{t}$} & \multirow[b]{2}{*}{ Sig. } & \multicolumn{2}{|c|}{$\begin{array}{c}\text { Collinearity } \\
\text { Statistics }\end{array}$} \\
\hline \multicolumn{2}{|c|}{ Model } & $\mathrm{B}$ & Std. Error & & & & Tolerance & VIF \\
\hline \multirow[t]{3}{*}{1} & (Constant) & .022 & .003 & & 8.119 & .000 & & \\
\hline & Inflasi & .002 & .005 & .042 & .313 & .755 & .943 & 1.060 \\
\hline & BIrate & -.043 & .041 & -.139 & -1.039 & .303 & .943 & 1.060 \\
\hline \multicolumn{3}{|c|}{ a. Dependent Variable: ROA } & & & & & & \\
\hline
\end{tabular}


Dari tabel diatas dapat dirumuskan persamaan regresi berdasarkan tabel sebagai berikut :

Dimana : $\mathrm{X}_{1=}$ Inflasi

$$
Y=0,022+0,002 X_{1}-0,043 X_{2}
$$

$$
\begin{aligned}
& \mathrm{X}_{2}=\text { BI Rate } \\
& \mathrm{Y}=\text { Return On Assets }(\mathrm{ROA})
\end{aligned}
$$

Dan dari persamaan di atas dijelaskan sebagai berikut :

a) Harga koefisien konstanta sebesar 0,022. Hal ini mengindikasikan bahwa apabila nilai inflasi dan BI Rate sama dengan nol, maka besarnya variabel Return On Assets sebesar 0,022 .

b) Harga koefisien inflasi $=0,002$, yang berarti apabila nilai inflasi mengalami kenaikan sebesar satu poin sementara variabel independen lainnya bersifat tetap, maka tingkat Return On Assets akan meningkat sebesar $0,2 \%$.

c) Harga koefisien BI Rate $=-0,043$, yang berarti apabila nilai BI Rate mengalami kenaikan sebesar satu poin sementara variabel independen lainnya bersifat tetap, maka tingkat Return On Assets akan menurun sebesar $4,3 \%$.

\section{Uji F}

Uji F dilakukan untuk mengetahui hubungan variabel independen, yaitu inflasi dan $B I$ Rate secara simultan (bersama-sama) terhadap variabel dependen, yaitu Return On Assets (ROA). Dalam uji F, diajukan hipotesis sebagai berikut :

$\mathrm{H}_{0} \quad$ : Diduga tidak terjadi hubungan signifikan antara Inflasi dan BI Rate terhadap $R O A$

$\mathrm{H}_{1} \quad$ : Diduga terjadi hubungan signifikan antara Inflasi dan BI Rate terhadap $R O A$.

$\alpha \quad: 5 \%(0,005)$

Kriteria Pengujian $\quad: \mathrm{H}_{0}$ diterima apabila nilai signifikansi $>$ dari $\alpha$

$\mathrm{H}_{0}$ ditolak apabila nilai signifikansi $<$ dari $\alpha$

Tabel 5. Uji F

\begin{tabular}{|l|l|r|r|r|r|r|}
\hline \multicolumn{7}{|c|}{ ANOVA $^{\text {b }}$} \\
\hline \multirow{2}{*}{ Model } & $\begin{array}{c}\text { Sum of } \\
\text { Squares }\end{array}$ & df & Mean Square & F & Sig. \\
\hline \multirow{3}{*}{1} & Regression & .000 & 2 & .000 & .542 & $.584^{\mathrm{a}}$ \\
\cline { 2 - 8 } & Residual & .000 & 58 & .000 & & \\
\cline { 2 - 7 } & Total & .000 & 60 & & & \\
\hline \multicolumn{2}{|l|}{ a. Predictors: (Constant), BIrate, Inflasi } & & & \\
\hline \multicolumn{2}{|l}{ b. Dependent Variable: ROA } & & & & \\
\hline
\end{tabular}

Dari hasil pengujian diatas, terlihat bahwa nilai signifikansi $\mathrm{F}$ sebesar 0,584 yang nilainya lebih besar dari 0,005 . Sehingga $\mathrm{H}_{0}$ diterima, yaitu inflasi dan $B I$ Rate secara bersama-sama tidak memiliki pengaruh signifikan terhadap Return On Assets (ROA). 


\section{Koefisien Determinasi}

Tabel 6. Uji Koefisien Determinasi

\begin{tabular}{|l|r|r|r|r|r|}
\hline \multicolumn{7}{|c|}{ Model Summary $^{\mathbf{b}}$} \\
\hline Model & \multicolumn{1}{|c|}{$\mathrm{R}$} & R Square & $\begin{array}{c}\text { Adjusted R } \\
\text { Square }\end{array}$ & $\begin{array}{c}\text { Std. Error of } \\
\text { the Estimate }\end{array}$ & Durbin-Watson \\
\hline 1 & $.135^{\mathrm{a}}$ & .018 & -.015 & .0027827 & .782 \\
\hline \multicolumn{2}{|l|}{ a. Predictors: (Constant), BI Rate, Inflasi } & & \\
\hline \multicolumn{2}{|l|}{ b. Dependent Variable: ROA } & & \\
\hline
\end{tabular}

Koefisien determinasi $\left(\mathrm{R}^{2}\right)$ digunakan untuk mengukur besar prosentase dari variabel dependen, yaitu Return On Assets (ROA) yang dapat dijelaskan oleh variabel independen, yaitu Inflasi dan BI Rate.

Dari hasil uji koefisien determinasi diatas, terlihat bahwa nilai $\mathrm{R}^{2}$ sebesar 0,018 atau sebesar $1,8 \%$. Sehingga bisa disimpulkan bahwa kontribusi nilai inflasi dan BI Rate menjelaskan variabel Return On Assets sebesar 1,8 \%, dan sisanya sebesar 98,2\% dipengaruhi oleh variabel lain yang tidak diteliti dalam penelitian ini.

\section{Pembahasan}

Pengaruh Variabel Inflasi terhadap Return On Assets (ROA)

Hasil penelitian ini menunjukkan bahwa variabel inflasi memiliki pengaruh positif dan tidak signifikan terhadap Return On Assets (ROA). Hal ini mengindikasikan bahwa semakin besar nilai inflasi, maka nilai Return On Assets akan meningkat meskipun tidak signifikan. Hal ini dikarenakan sistem Bank Syariah yang tidak menganut sistem bunga, sehingga uang yang dikelola tidak akan terlalu mengalami gejolak apabila mengalami inflasi seperti halnya Bank Konvensional.

\section{Pengaruh Variabel BI Rate terhadap Return On Assets (ROA)}

Hasil penelitian ini menunjukkan bahwa variabel BI Rate memiliki pengaruh negatif dan tidak signifikan terhadap Return On Assets (ROA). Hal ini disebabkan naiknya BI Rate akan memengaruhi kegiatan operasional Bank Syariah dalam hal pembiayaan dan penyaluran dana, sehingga hal tersebut dapat mengurangi pendapatan dan profit Bank Syariah meskipun tidak signifikan. 


\section{KESIMPULAN}

\section{Kesimpulan}

1. Variabel Inflasi secara parsial berpengaruh positif dan tidak signifikan terhadap Return On Assets (ROA). Sehingga hal ini menunjukkan bahwa $\mathrm{H}_{1}$ ditolak dan $\mathrm{H}_{0}$ diterima. Hal ini sesuai dengan penelitian Sahara (2013) yang menyatakan bahwa inflasi berpengaruh positif terhadap Return On Assets (ROA).

2. Variabel $B I$ Rate secara parsial berpengaruh negatif dan tidak signifikan terhadap Return On Assets (ROA). Sehingga hal ini menunjukkan bahwa $\mathrm{H}_{1}$ ditolak dan $\mathrm{H}_{0}$ diterima. Hal ini sesuai dengan penelitian Sahara (2013) bahwa BI Rate berpengaruh negatif terhadap Return On Assets (ROA).

3. a. Variabel Inflasi dan $B I$ Rate secara simultan tidak memiliki pengaruh signifikan terhadap Return On Assets (ROA). Sehingga dalam hal ini dikatakan $\mathrm{H}_{0}$ diterima. Hal ini sesuai dengan penelitian Supriyanti (2009) yang menyatakan inflasi dan $B I$ Rate tidak berpengaruh signifikan terhadap Return On Assets (ROA).

b. Nilai koefisien determinasi dari Uji-F sebesar 1,8 \%. Hal ini menjelaskan bahwa variabel inflasi dan BI Rate hanya mampu menjelaskan Return On Assets sebesar 1,8 \%, sedangkan 98,2\% sisanya dijelaskan oleh variabel lain yang tidak diteliti dalam penelitian ini.

4. Kesimpulan dari penelitian ini adalah bahwa variabel inflasi dan BI Rate tidak terlalu berpengaruh terhadap Return On Assets Bank Syariah di Indonesia. Hal ini dikarenakan Sistem Operasional Bank Syariah tidak menggunakan sistem bunga sehingga tidak terpengaruh secara langsung oleh adanya inflasi dan suku bunga perbankan. Namun sebagai lembaga keuangan, perubahan suku bunga akan berpengaruh pada resiko operasional bank syariah walaupun tidak secara signifikan.

\section{Saran}

1. Untuk peneliti selanjutnya diharapkan dapat menggunakan variabel independen yang lebih banyak seperti nilai tukar rupiah, karena Bank Syariah juga menjalankan aktivitas riil yang berkaitan dengan ekspor impor, produk domestik bruto untuk mengukur kesejahteraan masyarakat, serta variabel makroekonomi lain yang sesuai dengan topik penelitian.

2. Untuk peneliti selanjutnya diharapkan dapat mengkaji data dengan periode waktu yang lebih lama supaya data yang dihasilkan bisa lebih baik dan akurat. Hal ini dikarenakan keterbatasan pada penelitian ini sehingga menggunakan data dengan periode waktu yang relatif sedikit.

3. Untuk pihak perbankan syariah diharapkan bisa mengantisipasi resiko operasional bank syariah yang berkaitan dengan inflasi, misalnya dengan menghitung margin secara lebih seksama untuk pembiayaan yang bersifat fixed, sehingga dapat meminimalisir kerugian apabila terjadi inflasi sewaktuwaktu yang bisa menyebabkan biaya operasional meningkat. 
Syahirul Alim, Analisis Pengaruh Inflasi dan BI Rate... 217

\section{DAFTAR PUSTAKA}

Bungin, Burhan. 2004. Metodologi Penelitian Kuantitatif. Prenada Media Group. Jakarta.

Houston, Brigham. 2004. Dasar-dasar Manajemen Keuangan. Salemba Empat. Jakarta.

Huda, Nurul.dkk. 2008. Ekonomi Makro Islam : Pendekatan Teoretis. Prenada Media Group. Jakarta.

Iska, Syukri. 2012. Sistem Perbankan Syariah di Indonesia dalam Perspektif Fikih Ekonomi. Fajar Media Press. Yogyakarta.

Julianti, Friska. 2013. Analisis Pengaruh Inflasi, Nilai Tukar dan BI Rate terhadap Tabungan Mudharabah pada Perbankan Syariah. Skripsi. Jakarta. Fakultas Ekonomi dan Bisnis UIN Syarif Hidayatullah Jakarta.

Karim, Adiwarman A. 2006. Ekonomi Makro Islam. PT. Rajagrafindo Persada. Jakarta.

Karim, Adiwarman A. 2006. Bank Islam Analisis Fiqih dan Keuangan. PT. Rajagrafindo persada. Jakarta.

Kuncoro, Mudrajad. 2007. Metode Kuantitatif. UPP STIM YKPN. Yogyakarta.

Muhammad. 2005. Manajemen Pembiayaan Bank Syariah. UPP AMP YKPN. Yogyakarta.

Pohan, Aulia. 2008. Potret Kebijakan Moneter Indonesia. PT. RAJAGRAFINDO PERSADA. Jakarta.

Sahara, Ayu Yunita. 2013. Analisis Pengaruh Inflasi, Suku Bunga BI dan Produk Domestik Bruto terhadap Return On Assets (ROA) Bank Syariah di Indonesia. Jurnal Ilmu Manajemen Universitas Negeri Surabaya, Vol. 1 (1) : 149-157.

Sugiyono. 1999. Metode Penelitian Bisnis. Alfabeta, CV. Bandung.

Sunyoto, Danang. 2009. Uji Chi Kuadrat \& Regresi untuk Penelitian. Graha Ilmu. Yogyakarta.

Supomo, Bambang. 1999. Metodologi Penelitian Bisnis untuk Akuntansi dan Manajemen. BPFE-Yogyakarta. Yogyakarta.

Supriyanti, Neni. 2009. Analisis Pengaruh Inflasi dan Suku Bunga BI terhadap Kinerja Keuangan PT. Bank Mandiri, Tbk. Berdasarkan Rasio Keuangan. Jakarta. Universitas Gunadarma. 
Umar, Husein. 2003. Metode Riset Bisnis. PT. Gramedia Pustaka Utama. Jakarta.

Utami, Indrawati Setia. 2013. Analisis Pengaruh Inflasi, Suku Bunga, Kurs, dan Jumlah Uang Beredar terhadap Nisbah Bagi Hasil Deposito Mudarabah pada Bank Syariah Mandiri Tahun 2008-2012. Skripsi. Yogyakarta. Fakultas Syari'ah dan Hukum UIN Sunan Kalijaga Yogyakarta.

www.bi.go.id/id/moneter/inflasi/pengenalan/Contents/Default.aspx (diakses pada 21 April 2014)

www.bi.go.id/id/moneter/bi-rate/penjelasan/Contents/Default.aspx (diakses pada 21 April 2014) 
Lampiran 1 Data Inflasi, BI Rate, dan Return On Assets (ROA) Bank Syariah dalam periode waktu Oktober 2008 s/d Oktober 2013

\begin{tabular}{|c|c|c|c|c|}
\hline No. & Bulan & Inflasi & BI Rate & $R O A$ Bank Syariah \\
\hline 1 & Okt 2008 & 0.1117 & 0.095 & 0.0181 \\
\hline 2 & Nov 2008 & 0.1168 & 0.095 & 0.0168 \\
\hline 3 & Des 2008 & 0.1106 & 0.0925 & 0.0142 \\
\hline 4 & Jan 2009 & 0.0917 & 0.0875 & 0.0211 \\
\hline 5 & Feb 2009 & 0.086 & 0.0825 & 0.0215 \\
\hline 6 & Mar 2009 & 0.0792 & 0.0775 & 0.0244 \\
\hline 7 & Apr 2009 & 0.0731 & 0.075 & 0.0229 \\
\hline 8 & Mei 2009 & 0.0604 & 0.0725 & 0.0222 \\
\hline 9 & Jun 2009 & 0.0365 & 0.07 & 0.0216 \\
\hline 10 & Jul 2009 & 0.0271 & 0.0675 & 0.0212 \\
\hline 11 & Ags 2009 & 0.0275 & 0.065 & 0.0208 \\
\hline 12 & Sep 2009 & 0.0283 & 0.065 & 0.0138 \\
\hline 13 & Okt 2009 & 0.0257 & 0.065 & 0.0146 \\
\hline 14 & Nov 2009 & 0.0241 & 0.065 & 0.0148 \\
\hline 15 & Des 2009 & 0.0278 & 0.065 & 0.0148 \\
\hline 16 & Jan 2010 & 0.0372 & 0.065 & 0.0165 \\
\hline 17 & Feb 2010 & 0.0381 & 0.065 & 0.0176 \\
\hline 18 & Mar 2010 & 0.0343 & 0.065 & 0.0213 \\
\hline 19 & Apr 2010 & 0.0391 & 0.065 & 0.0206 \\
\hline 20 & Mei 2010 & 0.0416 & 0.065 & 0.0125 \\
\hline 21 & Jun 2010 & 0.0505 & 0.065 & 0.0166 \\
\hline 22 & Jul 2010 & 0.0622 & 0.065 & 0.0167 \\
\hline 23 & Ags 2010 & 0.0644 & 0.065 & 0.0163 \\
\hline 24 & Sep 2010 & 0.058 & 0.065 & 0.0177 \\
\hline 25 & Okt 2010 & 0.0567 & 0.065 & 0.0179 \\
\hline 26 & Nov 2010 & 0.0633 & 0.065 & 0.0183 \\
\hline 27 & Des 2010 & 0.0696 & 0.065 & 0.0167 \\
\hline 28 & Jan 2011 & 0.0702 & 0.065 & 0.0226 \\
\hline 29 & Feb 2011 & 0.0684 & 0.0675 & 0.0181 \\
\hline 30 & Mar 2011 & 0.065 & 0.0675 & 0.0197 \\
\hline 31 & Apr 2011 & 0.0616 & 0.0675 & 0.019 \\
\hline 32 & Mei 2011 & 0.598 & 0.0675 & 0.0184 \\
\hline 33 & Jun 2011 & 0.0554 & 0.0675 & 0.0184 \\
\hline 34 & Jul 2011 & 0.0461 & 0.0675 & 0.0186 \\
\hline 35 & Ags 2011 & 0.0479 & 0.0675 & 0.0181 \\
\hline 36 & Sep 2011 & 0.0461 & 0.0675 & 0.018 \\
\hline 37 & Okt 2011 & 0.0442 & 0.065 & 0.0175 \\
\hline 38 & Nov 2011 & 0.0415 & 0.06 & 0.0178 \\
\hline 39 & Des 2011 & 0.0379 & 0.06 & 0.0179 \\
\hline 40 & Jan 2012 & 0.0365 & 0.06 & 0.0136 \\
\hline 41 & Feb 2012 & 0.0356 & 0.0575 & 0.0179 \\
\hline 42 & Mar 2012 & 0.0397 & 0.0575 & 0.0183 \\
\hline 43 & Apr 2012 & 0.045 & 0.0575 & 0.0179 \\
\hline 44 & Mei 2012 & 0.0445 & 0.0575 & 0.0199 \\
\hline 45 & Jun 2012 & 0.0453 & 0.0575 & 0.0205 \\
\hline 46 & Jul 2012 & 0.0456 & 0.0575 & 0.0205 \\
\hline 47 & Ags 2012 & 0.0458 & 0.0575 & 0.0204 \\
\hline
\end{tabular}


220 MODERNISASI, Volume 10, Nomor 3, Oktober 2014

\begin{tabular}{|l|c|c|c|c|}
\hline 48 & Sep 2012 & 0.0431 & 0.0575 & 0.0207 \\
\hline 49 & Okt 2012 & 0.0461 & 0.0575 & 0.0211 \\
\hline 50 & Nov 2012 & 0.0432 & 0.0575 & 0.0209 \\
\hline 51 & Des 2012 & 0.043 & 0.0575 & 0.0214 \\
\hline 52 & Jan 2013 & 0.0457 & 0.0575 & 0.0252 \\
\hline 53 & Feb 2013 & 0.0531 & 0.0575 & 0.0229 \\
\hline 54 & Mar 2013 & 0.059 & 0.0575 & 0.0239 \\
\hline 55 & Apr 2013 & 0.0557 & 0.0575 & 0.0229 \\
\hline 56 & Mei 2013 & 0.0547 & 0.0575 & 0.0207 \\
\hline 57 & Jun 2013 & 0.059 & 0.06 & 0.021 \\
\hline 58 & Jul 2013 & 0.0861 & 0.065 & 0.0202 \\
\hline 59 & Ags 2013 & 0.0879 & 0.065 & 0.0201 \\
\hline 60 & Sep 2013 & 0.084 & 0.0725 & 0.0204 \\
\hline 61 & Okt 2013 & 0.0832 & 0.0725 & 0.0194 \\
\hline
\end{tabular}

Sumber : www.bi.go.id (data diolah dalam bentuk prosentase) 